\title{
Makalah :
}

\section{"Strategi Pengembangan UMKM dengan Mengatasi Permasalahan UMKM Dalam Mendapatkan Kredit Usaha"}

\section{Oleh :}

\author{
Rizka Zulfikar, S.TP, MM
}

\section{LATAR BELAKANG}

Usaha mikro, kecil dan menengah (UMKM) merupakan pelaku bisnis yang bergerak pada berbagai bidang usaha, yang menyentuh kepentingan masyarakat. Berdasarkan data BPS (2003), populasi usaha kecil dan menengah (UKM) jumlahnya mencapai 42,5 juta unit atau 99,9 persen dari keseluruhan pelaku bisnis di tanah air. UKM memberikan kontribusi yang signifikan terhadap penyerapan tenaga kerja, yaitu sebesar 99,6 persen. Semenrtara itu, kontribusi UKM terhadap Produk Domestik Bruto (PDB) sebesar 56,7 persen.

Dalam proses pemulihan ekonomi Indonesia, sektor UMKM memiliki peranan yang sangat stategis dan penting yang dapat ditinjau dari berbagai aspek. Pertama, jumlah industrinya yang besar dan terdapat dalam setiap sektor ekonomi. Berdasarkan data Badan Pusat Statistik (BPS) 2002, jumlah UMKM tercatat 41,36 juta unit atau $99,9 \%$ dari total unit usaha. Kedua, potensinya yang besar dalam penyerapan tenaga kerja. Setiap unit investasi pada sektor UMKM dapat menciptakan lebih banyak kesempatan kerja bila dibandingkan dengan investasi yang sama pada usaha besar. Sektor UMKM menyerap 76,55 juta tenaga kerja atau 99,5\% dari total angkatan kerja yang bekerja. Ketiga, kontribusi UMKM dalam pembentukan PDB cukup signifikan yakni sebesar 55,3\% dari total PDB.

Salah satu upaya peningkatan dan pengembangan UMKM dalam perekonomian nasional dilakukan dengan mendorong pemberian kredit modal usaha kepada UMKM. Dari sudut perbankan, pemberian kredit kepada UMKM menguntungkan bagi bank yang bersangkutan. Pertama, tingkat kemacetannya 
relatif kecil. Hal ini terutama disebabkan oleh tingkat kepatuhan nasabah usaha kecil yang lebih tinggi dibandingkan nasabah usaha besar. Kedua, pemberian kredit kepada UMKM mendorong penyebaran risiko, karena penyaluran kredit kepada usaha kecil dengan nilai nominal kredit yang kecil memungkinkan bank untuk memperbanyak jumlah nasabahnya, sehingga pemberian kredit tidak terkonsentrasi pada satu kelompok atau sektor usaha tertentu. Ketiga, kredit UMKM dengan jumlah nasabah yang relatif lebih banyak akan dapat mendiversifikasi portofolio kredit dan menyebarkan risiko penyaluran kredit. Keempat, suku bunga kredit pada tingkat bunga pasar bagi usaha kecil bukan merupakan masalah utama, sehingga memungkinkan lembaga pemberi kredit memperoleh pendapatan bunga yang memadai. Pengalaman selama ini menunjukkan bahwa ketersediaan dana pada saat yang tepat, dalam jumlah yang tepat, sasaran yang tepat dan dengan prosedur yang sederhana lebih penting dari pada bunga murah maupun subsidi.

Namun dari beberapa hal yang melatar belakangi seperti tersebut di atas, masih belum cukup menjadi landasan keyakinan bahwa pelaku UMKM akan mendapatkan kemudahan dalam hal pengajuan fasilitas kredit modal usaha ke lembaga-lembaga pemberi kredit baik perbankan maupun non perbankan. Hingga saat ini masih banyak pelaku UMKM yang mengalami permasalahan dalam hal pengajuan kredit usaha.

\section{TUJUAN PENULISAN}

Adapun tujuan dari makalah ini antara lain adalah :

a) Mengidentifikasi kesulitan dan permasalahan yag dihadapi UMKM dalam mendapatkan kredit modal usaha.

b) Menentukan strategi pengembangan UMKM melalui peningkatan kemudahan pemberian fasilitas kredit modal usaha melalui lembaga penyalur kredit 


\section{TINJAUAN PUSTAKA}

Menurut Winarni (2006) Pada umumnya, usaha kecil mempunyai ciri antara lain sebagai berikut (1) Biasanya berbentuk usaha perorangan dan belum berbadan hukum perusahaan, (2) Aspek legalitas usaha lemah, (3) Struktur organisasi bersifat sederhana dengan pembagian kerja yang tidak baku, (4) Kebanyakan tidak mempunyai laporan keuangan dan tidak melakukan pemisahan antara kekayaan pribadi dengan kekayaan perusahaan, (5) Kualitas manajemen rendah dan jarang yang memiliki rencana usaha, (6) Sumber utama modal usaha adalah modal pribadi, (7) Sumber Daya Manusia (SDM) terbatas, (7) Pemilik memiliki ikatan batin yang kuat dengan perusahaan, sehingga seluruh kewajiban perusahaan juga menjadi kewajiban pemilik.

Badan Pusat Statistik (2003) mengidentifikasikan permasalahan umum yang dihadapi oleh UMKM adalah (1) Kurang permodalan, (2) Kesulitan dalam pemasaran, (3) Persaingan usaha ketat, (4) Kesulitan bahan baku, (5) Kurang teknis produksi dan keahlian, (6) Keterampilan manajerial kurang, (7) Kurang pengetahuan manajemen keuangan, dan (8) Iklim usaha yang kurang kondusif (perijinan, aturan/perundangan)

Hasil penelitian kerjasama Kementerian Negara KUKM dengan BPS (2003) di dalam Sri Winarni (2006) menginformasikan bahwa UKM yang mengalami kesulitan usaha $72,47 \%$, sisanya $27,53 \%$ tidak ada masalah. Dari 72,47 \% yang mengalami kesulitan usaha tersebut, diidentifikasi kesulitan yang muncul adalah (1) Permodalan 51,09 \%, (2) Pemasaran 34,72 \%, (3) Bahan baku 8,59\%, (4) Ketenagakerjaan 1,09\%, (5) Distribusi transportasi 0,22\% dan (6) Lainnya 3,93\%.

Persentase kesulitan yang dominan dihadapi UMKM terutama meliputi kesulitan permodalan (51.09\%). Lebih lanjut disebutkan bahwa dalam mengatasi kesulitan permodalannya diketahui sebanyak 17,50 \% UKM menambah modalnya dengan meminjam ke bank, sisanya 82,50 \% tidak melakukan pinjaman ke bank tetapi ke lembaga Non bank seperti Koperasi 
Simpan Pinjam (KSP), perorangan, keluarga, modal ventura, lainnya. Sedangkan permasalahan yang dihadapi UMKM dalam mendapatkan kredit modal usaha antara lain adalah (1) Prosedur pengajuan yang sulit 30,30\%, (2) Tidak berminat 25,34 \%, (3) Pelaku UMKM Tidak punya agunan 19,28 \%, (4) UMKM yang tidak tahu prosedur $14,33 \%$, (5) Suku bunga tinggi 8,82 \%,, (6) Proposal ditolak (1,93\%).

Menurut Winarti (2004) dengan mempertimbangkan peran penting UMKM dalam berbagai aspek perekonomian dan dalam upaya percepatan pemulihan kegiatan ekonomi, Bank Indonesia memberikan dukungan dalam pengembangan UMKM. Dukungan Bank Indonesia ini termasuk juga dalam rangka mendorong pulihnya fungsi intermediasi perbankan dan menciptakan kondisi perbankan yang sehat.

Dalam rangka mendukung pemberdayaan dan pengembangan UMKM terutama dalam mendorong penyaluran kredit kepada UMKM, upaya Bank Indonesia antara lain melalui penerapan kebijakan kredit, pemberian bantuan teknis kepada UMKM melalui Konsultan Keuangan Mitra Bank, penelitian mengenai pola pembiayaan kepada UMKM, penyediaan sistem informasi pembiayaan usaha kecil dan pemberian bantuan teknis.

\section{PEMBAHASAN}

Melihat paparan di atas, maka dapat dikatakan bahwa kesulitan yang dihadapi UMKM dalam antara lain adalah : (1) Kurang permodalan, (2) Kesulitan dalam pemasaran, (3) Persaingan usaha ketat, (4) Kesulitan bahan baku, (5) Kurang teknis produksi dan keahlian, (6) Keterampilan manajerial kurang, (7) Kurang pengetahuan manajemen keuangan, dan (8) Iklim usaha yang kurang kondusif (perijinan, aturan/perundangan).

Sedangkan permasalahan yang mendasar yang umumnya dihadapi oleh UMKM dalam mendapatkan permodalan usaha adalah karena prosedur pengajuan yang sulit, tidak adanya agunan, ketidaktahuan tentang prosedur dan 
suku bunga tinggi. Dari beberapa permasalahan yang disebutkan di atas, yang menjadi masalah internal hanyalah faktor ketidaktahuan tentang prosedur sedangkan faktor lainnya adalah adalah faktor eksternal (sisi kreditor).

Jika dilihat dari sisi kreditor( pemodal atau lembaga pembiayaan), untuk melindungi resiko kredit, menuntut adanya kegiatan bisnis yang dijalankan dengan prinsip-prinsip manajemen modern, ijin usaha resmi serta adanya jaminan (collateral). Perbedaan persfektif antara permasalahan yang dihadapi UMKM dengan ketentuan yang harus ditaati oleh lembaga penyalur kredit inilah yang menjadi alasan mendasar mengapa para pelaku UMKM masih menemui kesulitan dalam mendapatkan kredit modal usaha.

Melihat kebijakan dan bantuan teknis Bank Indonesia yang sudah ada, maka ada beberapa upaya yang dapat dilakukan dalam rangka memberikan kemudahan bagi UMKM dalam mendapatkan kredit modal usaha, antara lain :

\section{a. Mengoptimalkan peran Konsultan Keuangan Mitra Bank (KKMB)}

Konsultan Keuangan Mitra Bank (KKMB) adalah lembaga atau bagian dari lembaga yang memberikan layanan pengembangan usaha dalam rangka meningkatkan kinerja Usaha Mikro, Kecil dan Menengah (UMKM). Lembaga tersebut berbadan hukum dan bukan lembaga keuangan serta dapat memperoleh fee dari jasa layanannya. Jasa yang diberikan adalah jasa konsultansi dalam hal manajemen/analisis keuangan agar terjadi kemitraan dengan bank atau terjadinya penyaluran dana bank kepada UMKM tersebut. Dalam hal ini termasuk pendampingan pada saat menyusun proposal kredit, menghubungkan ke lembaga pembiayaan/bank dan melakukan monitoring sejak saat pencairan kredit sampai pada pelunasan kredit sesuai jangka waktu yang diperjanjikan.

Fungsi dan tanggung jawab KKMB adalah melakukan pembinaan dan pengembangan terhadap UMKM. Pembinaan disini dimaksudkan adalah merupakan satu kesatuan proses yang di dalamnya mencakup tiga unsur yaitu menumbuhkan, memelihara dan megembangkan. Proses pelaksanaan 
pembinaan oleh KKMB dilakukan secara partisipatif, bahwa segala sesuatu yang berhubungan dengan pembinaan (materi, metode dll) harus selalu bertumpu pada kebutuhan UMKM, oleh karenanya hubungan kerja antara KKMB dengan UMKM bukanlah sebagai atasan dan bawahan atau hubungan antara pembina dengan yang dibina. Hubungan yang terjalin adalah sejajar dan KKMB disini berperan sebagai motivator bagi UMKM.

Bentuk kegiatan pembinaan dan pengembangan disini adalah melakukan pendampingan terhadap UMKM dengan memberikan bantuan teknis berupa pelatihan sesuai kebutuhan, arahan dan konsultasi. Untuk melakukan kegiatan tersebut seorang KKMB dalam pelaksanaannya di lapangan berpedoman pada beberapa langkah sebagai berikut :

- Melakukan identifikasi pada calon nasabah UMKM di wilayah/sentra/populasi usaha;

- Menentukan kelompok bila memperoleh calon nasabah mikro dalam rangka efisiensi;

- Menyusun proposal kredit (usaha mikro) atau Kelayakan usaha ( usaha kecil dan menengah);

- Menghubungkan nasabah UMKM tersebut dengan perbankan;

- Melakukan monitoring dan pendampingan pasca penerimaan kredit

Diharapkan dengan adanya optimalisasi peran dari $\mathrm{KKMB}$, persyaratan dan prosedur yang ditetapkan oleh Lembaga penyalur kredit, tidak lagi menjadi kendala bagi UMKM dalam mendapatkan kredit modal usaha. Keberhasilan dari pendekatan ini akan nampak dari meningkatnya jumlah UMKM yang bankable dan memperoleh kredit modal usaha, dan mampunya KKMB beroperasi secara bisnis (saling menguntungkan) sehingga dapat membiayai dirinya sendiri. 


\section{b. Mensosialisasikan Pola Pembiayaan Bagi Hasil atau Pembiayaan Modal Ventura}

Bagi beberapa UMKM yang merasa terbebani dengan suku bunga tinggi, kebutuhan modal usaha dapat diajukan ke lembaga pembiayaan yang menerapkan pola kerjasama dengan bagi hasil. Dimana return yang diberikan UMKM sesuai dengan hasil yang didapatkan UMKM pada saat itu sehingga UMKM tidak terbebani dengan tingkat suku bunga yang tinggi. Lembaga pembiayaan yang menerapkan pola bagi hasil adalah Perusahaan Pembiayaan Modal Ventura dengan konsep bagi hasil murni ataupun bagi hasil terkelola.

Dari segi karakteristik Modal Ventura yang bersifat Gain Risk (cenderung lebih berani mengambil resiko), pembiayaan ini memiliki prosedur yang lebih longgar dan lebih mengutamakan prospek dan potensi usaha UMKM dalam pengembangannya. Pembiayaan ini dapat dilakukan dalam jangka waktu pendek maupun panjang (maksimal 4 tahun).

Pembiayaan Modal Ventura tidak hanya menyalurkan dana-dana yang berasal dari pemegang saham dan pinjaman perbankan tetapi juga ikut menyalurkan dana-dana program pemerintah dengan rate yang lebih murah daripada rate kredit komersil. Adapun dana-dana program yang disalurkan oleh perusahaan Modal Ventura antara lain seperti dana LPDB (Lembaga Pengelola Dana Bergulir) dan Dana PKBL (Program Kemitraaan Bina Lingkungan) dari PT. Bahana Artha Ventura dan LPEI (Lembaga Pengelola Ekspor Indonesia)

Diharapkan dengan digiatkannya sosialisasi pembiayaan modal ventura, UMKM yang memiliki permasalahan dalam hal bunga kredit tetap mendapatkan kredit modal usaha baik dalam bentuk kerjasama pembiayaan pola bagi hasil ataupun kredit program LPDB dan PKBL. 


\section{c. Meningkatkan peran serta Lembaga Penjaminan Kredit}

Alternatif lain yang dapat digunakan untuk mengatasi permasalahan perkreditan UMKM adalah skim penjaminan kredit. Dalam skim tersebut, Bank dan Perusahaan Penjamin membuat suatu perjanjian kerjasama penjaminan kredit. UMKM yang membutuhkan tambahan modal dari lembaga penyalur kredit mengajukan penjaminan kepada Perusahaan Penjamin dan mengajukan kredit kepada Bank. Apabila hasil analisis kelayakan, usaha dinyatakan layak (feasible), namun tidak layak dari sudut pandang perbankan karena ketidakcukupan agunan (tidak bankable), maka bank mengajukan penjaminan kepada Perusahaan Penjamin. Selanjutnya Perusahaan Penjamin akan melakukan analisa kelayakan. Apabila Kredit tersebut dinyatakan layak untuk dijamin, maka Perusahaan Penjamin akan memberikan penjaminan kepada usaha kecil yang dinyatakan dalam bentuk Sertfikat Penjaminan. Atas penjaminan yang diberikan tersebut, usaha kecil yang dijamin harus membayar fee penjaminan kepada Perusahaan Penjamin.

Apabila kredit yang dijamin mengalami kemacetan, maka Perusahaan Penjamin akan melakukan pengecekan, apakah kondisi yang ada memenuhi persyaratan dan ketentuan yang telah disepakati oleh Perusahaan Penjamin dengan Bank. Apabila segala persyaratan telah terpenuhi, maka Perusahaan Penjamin akan melakukan pembayaran klaim. Selanjutnya, Perusahaan Penjamin berhak mendapatkan piutang subrogasi sebesar porsi kredit yang dijamin. Setelah pembayaran klaim dilakukan, Bank masih tetap harus melakukan penagihan sampai dengan hutang tersebut lunas. Hasil penagihan tersebut dibagi secara proporsional antara Perusahaan Penjamin dan Bank sesuai dengan persentase penjaminan kredit. Dengan adanya penjaminan kredit tersebut, maka :

- Pengajuan kredit oleh usaha kecil yang sebelumnya tidak memenuhi persyaratan perbankan menjadi bankable, sehingga UMKM dapat mengembangkan usahanya. 
- Risiko Bank menjadi berkurang, karena sebagian telah dialihkan menjadi risiko Perusahaan Penjamin. Dengan terpenuhinya kecukupan agunan dan berkurangnya risiko, maka kemungkinan terjadinya penolakan proposal pinjaman menjadi lebih kecil.

- Perusahaan Penjamin juga melakukan kelayakan dan pengendalian atas kredit yang dijamin. Dengan adanya dan pengendalian dari dua pihak yang berlainan diharapkan risiko dapat lebih diminimalkan.dan

- Perusahaan Penjamin akan mendapatkan pendapatan fee penjaminan.

Diharapkan dengan adanya skim penjaminan kredit bagi UMKM ini, maka para UMKM yang mengalami permasalahan dalam hal agunan dapat teratasi karena adanya jaminan dari lembaga penjamin kredit. Pihak lembaga penyalur kredit pun akan merasa kebih aman dalam menyalurkan kreditnya kepada UMKM.

\section{KESIMPULAN}

UMKM sangat dominan dibandingkan dengan kelompok skala usaha lainnya. Di samping itu, peran usaha kecil dalam menyerap tenaga kerja relatif besar. Sehingga pengembangan usaha merupakan langkah strategis dalam meningkatkan kesejahteraan masyarakat dan pertumbuhan ekonomi nasional. Lebih dari 50\% UMKM mengalami kesulitan permodalan. UMKM yang memanfaatkan sumber permodalan eksternal dari lembaga penyalur kredit hanya sebesar $17,50 \%$. Alasan UMKM belum memanfaatkan kredit sebagian besar adalah faktor kebijakan, persyaratan dan tingkat suku bunga kredit yang cukup tinggi.

Untuk itu dalam rangka lebih mengembangkan UMKM, maka ada beberapa strategi yang dapat dilakukan antara lain adalah (1) Mengoptimalkan peran KKMB dalam membina dan melakukan pendampingan para UMKM prospek yang akan mengajukan permohonan kredit usaha, (2) mensosialisasikan pembiayaan bagi hasil atau modal ventura, (3) Meningkatkan peran serta 
lembaga penjamin kredit untuk para UMKM prospek yang terbentur akan adanya persyaratan agunan. Diharapkan dengan dilaksanakannya strategistrategi di atas, para UMKM prospek tidak lagi mengalami kesulitan dalam hal pengajuan kredit modal usaha dari Lembaga Penyalur Kredit.

\section{DAFTAR PUSTAKA}

Rahayu, S.L 2005, Analisis Peranan Perusahaan Modal Ventura Dalam Mengembangkan UKM Di Indonesia, Kajian Ekonomi dan Keuangan,Badan Pengkajian Ekonomi, Keuangan dan Kerjasama Internasional.

Mulyati, S.T. S, 2004. Kebijakan dan Strategi Pengembangan Bank Indonesia dalam Mendukung Pelayanan Keuangan yang Berkelanjutan bagi Usaha Mikro, Kecil dan Menengah. Deputi Direktur Direktorat Pengawasan Bank Perkreditan Rakyat.

Winarni, S. 2006. Strategi Pengembangan Usaha Kecil Melalui Peningkatan Aksesibilitas Kredit Perbankan. Infokop Nomor 29 Tahun XXII, 2006. 